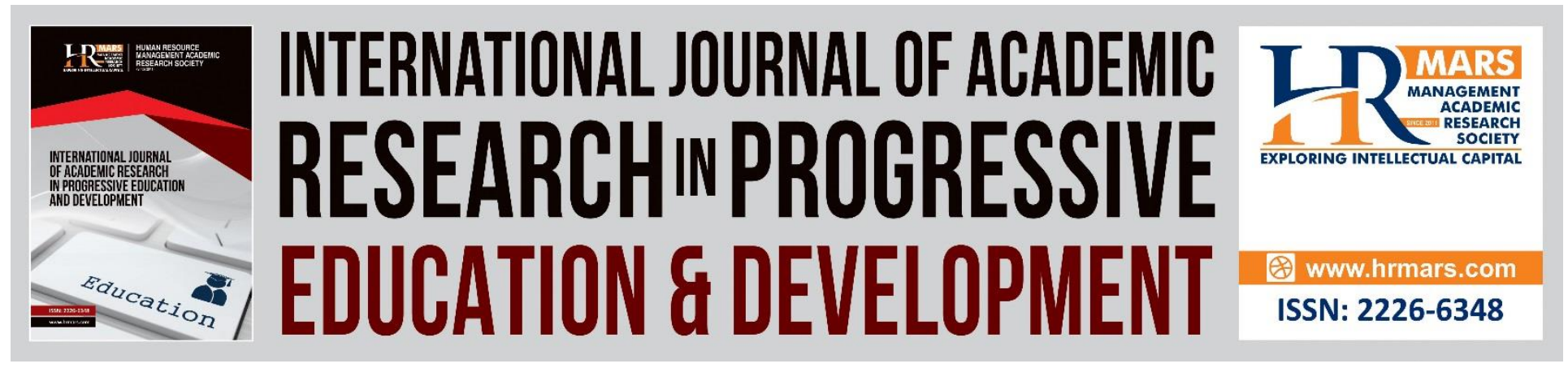

\title{
To Tell or Not to Tell: Exploring Malaysian Teachers' Perceptions towards Storytelling in English Classrooms
}

\author{
Husna Yahya, Abu Bakar Razali \& Roselan Baki
}

To Link this Article: http://dx.doi.org/10.6007/IJARPED/v7-i4/5020

DOI: $10.6007 /$ IJARPED/v7-i4/5020

Received: 09 Nov 2018, Revised: 28 Nov 2018, Accepted: 14 Dec 2018

Published Online: 23 Dec 2018

In-Text Citation: (Yahya, Razali, \& Baki, 2018)

To Cite this Article: Yahya, H., Razali, A. B., \& Baki, R. (2018). To Tell or Not to Tell: Exploring Malaysian Teachers' Perceptions towards Storytelling in English Classrooms. International Journal of Academic Research in Progressive Education and Development, 7(4), 303-323.

Copyright: (C) 2018 The Author(s)

Published by Human Resource Management Academic Research Society (www.hrmars.com)

This article is published under the Creative Commons Attribution (CC BY 4.0) license. Anyone may reproduce, distribute, translate and create derivative works of this article (for both commercial and non-commercial purposes), subject to full attribution to the original publication and authors. The full terms of this license may be seen at: http://creativecommons.org/licences/by/4.0/legalcode

\section{Vol. 7, No. 4, 2018, Pg. 303 - 323}

Full Terms \& Conditions of access and use can be found at http://hrmars.com/index.php/pages/detail/publication-ethics 


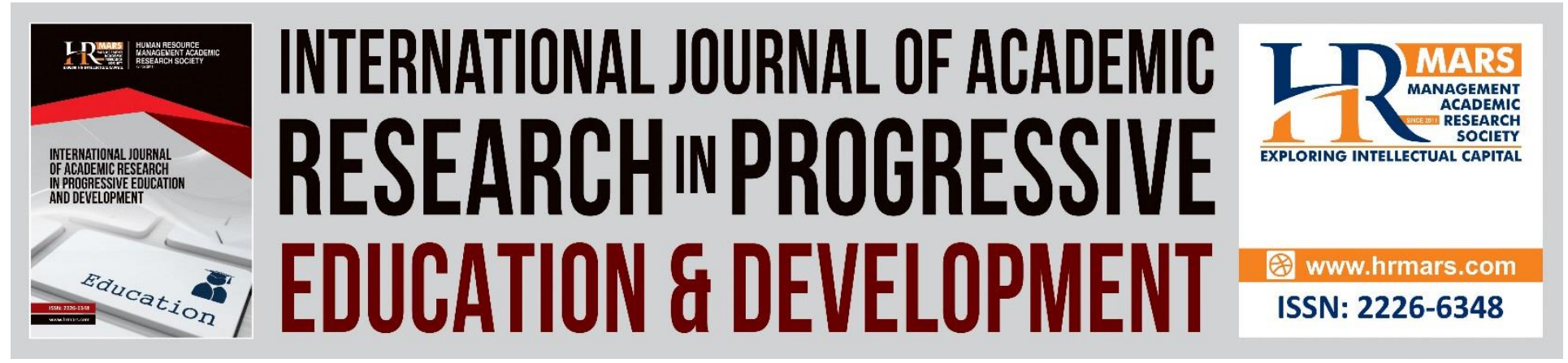

\title{
To Tell or Not to Tell: Exploring Malaysian Teachers' Perceptions towards Storytelling in English Classrooms
}

\author{
Husna Yahya, Abu Bakar Razali \& Roselan Baki \\ Faculty of Educational Studies, University Putra Malaysia, 43400 UPM Serdang, Selangor Darul \\ Ehsan, Malaysia
}

\begin{abstract}
This qualitative study explores the in-service teachers' perceptions towards storytelling as a pedagogical strategy and also examines how and to what extent storytelling is being used as a teaching tool in Malaysian English classrooms. This study is guided by three research questions: 1) How are storytelling strategies perceived and used among the teachers to teach English in the classrooms?; 2) How often do teachers use the storytelling strategies in their lessons and for what purpose; and 3) What challenges do teachers experience while working with the storytelling strategies in their lessons, and how do they deal with these challenges? Three primary school teachers from Melaka Tengah District, Melaka were chosen via purposive sampling and from the semi-structured interview conducted, the researchers found that the teachers have a very positive outlook on using storytelling as one of the teaching strategies. However, challenges like insufficient training, time constraint, students' low proficiency, and exam-oriented and rigid education system hinder them from fully utilising this strategy in their teaching practice. This paper discusses several implications and provide several suggestions to alleviate these concerns and to promote the use of storytelling in the teaching of English.
\end{abstract}

Keywords: Perception, Storytelling, Teaching Strategy, Malaysian English Classrooms

\section{Introduction}

Creating fun, meaningful and memorable lessons should be the utmost priority for English teachers. Such lessons would benefit the ESL students to learn English in a more relaxing and comfortable manner. When the students really enjoy themselves during the lesson, it would help them to learn English more effectively. As DiCarlo (2009) stated, learning should be fun because when fun in learning is successfully achieved, the students would be highly motivated to really learn. 


\section{INTERNATIONAL JOURNAL OF ACADEMIC RESEARCH IN PROGRESSIVE EDUCATION AND}

DEVELOPMENT

Vol. 7, No. 4, 2018, E-ISSN: 2226-6348 @ 2018 HRMARS

There are many studies done to look at how the teachers teach listening, speaking, reading and writing and also grammar and vocabulary in Malaysian English classrooms. For instance, Choy and Troudi (2006), Lim (2013), Thang, Ting, and Nurjanah (2011) and Normazidah, Lie, and Hazita (2012) have shown glimpses into the pedagogical practices and the reality of teaching and learning of English in Malaysian classrooms. The crucial findings from these research show that English teachers seem to focus more on the task of preparing the students for the public examinations; not because they wanted to, but because of the mounting pressure of producing good results in the national examinations. Consequently, their pedagogical strategies seem to congregate around memorization and rote learning; where more often than not the skills are taught as a set of language mechanics with 'fixed' ways of using the language and very isolated from its communicative use, only to be learned and mastered for specific classroom situations. This effected badly on the students' performance in learning English; not just during their primary and secondary schooling years, but also during their tertiary education and their lives after that.

As stated by Normazidah et al. (2012), the focus on mastering and rote learning of skills and applying them in examinations eventually eroded communicative competence. Consequently, a new class of students emerged; where they could pass the examinations and continue to the tertiary level without actually being able to use the English language productively in a communicative event. The transitions that Malaysian students have to make from schools to higher institutions of learning may be difficult because of the existing patterns of learning that emphasize more on surface learning, rote memorization and dependent learning rather than deep learning that is more exploratory and analytical (Anis, Mahani, Latisha Asmaak, \& Surina, 2009). The lack of soft skills amongst Malaysian undergraduates is partly attributed to the rote learning style adopted by Malaysian school children who are pressured to excel academically and in the process, they fail to develop an inquisitive mind and analytical skills (Ahmad, 1998; cited in Roselina, 2009). Therefore, many school leavers and fresh graduates fail to secure employment after graduation. Malaysia Employers Federation (MEF) Executive Director, Datuk Shamsuddin Bardan said there was still a major problem among job seekers, especially fresh graduates, school leavers and diploma holders to secure jobs since some of them were unable to construct proper sentences nor convey the messages during job interviews conducted in English (The Star Online, 2017).

The examples above show the severity of rote learning and memorization in English language acquisition and how they have scarred the students' abilities to learn and use English well in life. Rote learning, memorization, choral repetition and copying from the board are some of the outmoded teaching strategies that need to be revamped. Since teachers are the key players to change this classroom paradigm, the focus should be more intense on changing the pedagogical practices and the teachers' mindsets, i.e., in changing the pedagogical approaches to have more meaningful, fun and enjoyable activities in the classrooms; particularly for English language subject which emphasizes on the importance of communicative skills. There are many ways to create fun, enjoyable and meaningful English lessons. One of the ways that this study is interested in is by using storytelling as an English language teaching strategy. 


\section{Storytelling: Its Benefits and Challenges}

Roney (1996) defines storytelling as a process where a person (the teller), using vocalization, narrative structure, and mental imagery, communicates with the audience who also use mental imagery and, in turn, communicate back to the teller primarily through body language and facial expression in an ongoing communication cycle. Thus, it makes storytelling co-creative and interactive. Storytelling is one of the most powerful forms of art/communication known to humans and this explains why it possesses such great potential as a teaching-learning tool.

There are many benefits of storytelling in teaching English. Maguire (1985; cited in Shirley, 2005) stated there are numerous educational and social benefits of storytelling, such as increasing vocabulary, concentration, and the ability to think symbolically and metaphorically. This means when a child listens to a story, it would : 1) help him/her be sensitive to various forms of syntax, diction, and rhetoric; 2) recognize patterns in language and in human experience; 3) stimulate overall powers of creativity; 4) equip the child with problem-solving and decision-making exercises; 5) strengthen his/her capacity to form objective, rational, and practical evaluations; 6) assist in developing his/her skills in dialogue and cooperative interpersonal behaviour; and 7) familiarize him/her with the symbols, artefacts, and traditions that are part of one's own cultural heritage and the cultural heritages of others. In short, storytelling is not only good for practicing and learning the English language, it can also be a very powerful tool for initiating, encouraging, and manipulating the thinking process in students.

Storytelling in ESL classrooms is often used informally by teachers to share cultural and personal information, such as telling stories about one's experiences while growing up. Storytelling has always been a popular and effective strategy to teach the English language to non-native speakers (Fitzgibbon \& Wilhelm, 1998). In education, teachers (as tellers) could plan to work with audiences in a learning environment by using stories to instil the love of target language in their students (Suzuki, 2000). Storytelling in the ESL/EFL classrooms is not a passive learning for students. It is a live, person-to-person oral presentation to the students as audience. As such, storytelling becomes an interactive performance art form; both as an art form and a means of communication (Suzuki, 2000, \& Roney, 1996). This is because the direct interaction between the teller and audience is an essential element of the storytelling experience.

Although storytelling poses numerous benefits in teaching English, this strategy seems less favourable and underutilised by the teachers in the Malaysian classrooms. Based on the studies done by Choy and Troudi (2006), Lim (2013), Thang, Ting, and Nurjanah (2011) and Normazidah, Lie, and Hazita (2012), the English teachers in their studies are more in favour with memorization and rote learning strategies. Their teaching and learning strategies are mostly very mechanical and structured, which are tailored to be learned and mastered for specific classroom set ups. Consequently, most students are unable to use their communicative strategies effectively in real life communicative situations.

Since storytelling has numerous educational and social benefits, one wonders why the teachers do not employ some of the storytelling strategies in their English lessons. Perhaps these teachers' perceptions are grounded in what they believe in, i.e., their cognition (or teacher cognition). As 

DEVELOPMENT

Vol. 7, No. 4, 2018, E-ISSN: 2226-6348 ๑ 2018 HRMARS

stated by Borg (2003), the term teacher cognition refers to the unobservable cognitive dimension of teaching, i.e., what teachers know, believe, and think. The teachers are active, thinking decision-makers who make instructional choices by drawing on complex, practically-oriented, personalised, and context-sensitive networks of knowledge, thoughts, and beliefs. Therefore, there is a connection between the relationships of these mental constructs to what teachers do in the language teaching classroom. Borg (2012; cited in Birello, 2012) added that if we want to promote change in the classrooms, understanding what the teachers do is not enough, we also need to understand and look at their beliefs or their cognition that affects their teaching. In this regard, this study is interested to explore the teachers' perceptions towards storytelling in relation with their own beliefs and their actual practices in using storytelling as a pedagogical strategy to teach English in the classroom. Perhaps by understanding the teachers' beliefs, it could help to understand their perceptions and thus would help to find ways to promote change in the classroom practices to better heights.

\section{Research Aims and Objectives}

This study's main aim is to explore the in-service teachers' perceptions towards storytelling as a pedagogical strategy in teaching English in Malaysian classrooms. This study also aims to examine how and to what extent storytelling is being used as a tool in teaching English in primary school classrooms. As such, this study was guided by these three research questions:

1. How are storytelling strategies perceived and used among teachers to teach English in the classrooms?

2. How often do teachers use the storytelling strategies in their English lessons and for what purpose?

3. What challenges do teachers experience while working with storytelling strategies in their English lessons and how do they deal with these challenges?

\section{Methodology}

This study employs a qualitative case study design, which is deemed appropriate for this research as it involves the study of a case within a real-life, contemporary context or setting (Yin, 2009). Hence, this design helps to achieve this study's aims to explore the in-service teachers' perceptions towards storytelling as a teaching strategy and examine how and to what extent storytelling is being used as a teaching tool in English classrooms. This small scale case study used only one type of data collection method, i.e., a semi-structured interview. This type of interview permits the researchers to be more flexible with more open-ended and less structured questions as this format allows the researchers to respond to the situation at hand; to the emerging worldview of the respondents, and to new ideas on the topic (Merriam \& Tisdell, 2016). Using semi-structured interview is adequate to gain much needed information on the teachers' perceptions towards storytelling and to understand in depth of their own perceptions, beliefs, experience and challenges that the teachers face when they use storytelling strategies in their own English classrooms. An interview protocol and a consent form was prepared for each teacher before the interview and each teacher was given the chance to go through the questions in the interview protocol before the interview began. 


\section{INTERNATIONAL JOURNAL OF ACADEMIC RESEARCH IN PROGRESSIVE EDUCATION AND}

DEVELOPMENT

Vol. 7, No. 4, 2018, E-ISSN: 2226-6348 @ 2018 HRMARS

The questions for the interview mostly stemmed from the main research questions; 1) How are storytelling strategies perceived by the teachers?, 2) How are the storytelling strategies used to teach English in the classrooms?, 3) How often the teachers used storytelling strategies in their lessons?, 4) What is the purpose of them using storytelling strategies in their lessons?, 5) What challenges do the teachers experienced while working with the storytelling strategies in their lessons, and 6) How the teachers deal with the challenges that they faced? These main questions in the interview protocol were aided by sub-questions, open-ended and probing questions that were asked based on the answers and responses given by the participants during the interview. The interview is done individually and each interview is recorded and then transcribed verbatim. The overall length of the interview with each teacher was around one hour. From the transcriptions, the data was analysed by using constant comparative method to form codes, categories and themes. The themes are formed in line with the three research questions of this study.

This small scale case study used purposive sampling in order to identify and choose three primary school English teachers as participants. The three participants chosen were from Melaka Tengah District, Melaka. These teachers were selected because they have all the characteristics of good respondents as stated by Merriam and Tisdell (2016), in which they understood the culture and context of this study and are able to reflect on it; they could express their thoughts, feelings, opinions and offered their perspectives on the topic being studied; and they were also willing to share their expertise and enjoyed to have the opportunity to clarify their own thoughts and experiences. The three participants were also purposively chosen for this research because they fit the sampling criteria set by this case study, which are: 1) they have been teaching for more than 7 years, which means that they have ample teaching experience; 2 ) their teacher education background has to be of that of an English major, which means they are fully trained to teach English to primary school students; and 3) all three of them are currently teaching in three different school settings or different school backgrounds, which are in rural, sub-urban and town/urban areas so that the perceptions of the teachers who are teaching in three different school backgrounds could be explored.

Teacher 1 is teaching in a rural area in Melaka Tengah District. She is 34 years old and she has 8 years of teaching experience. She is an English major and was fully trained to teach English for primary school students. Her school is located in a rural, village area and almost all of the students there do not speak English at home.

Teacher 2 is teaching in a sub-urban area in Melaka Tengah District. She is 51 years old and she has 26 years of teaching experience. She is an English major and was fully trained to teach English for primary school students. Her school is located in a sub-urban housing area and the majority of the students there do not speak English at home.

Teacher 3 is teaching right in the middle of the urban area in Melaka Tengah District. She is 50 years old and she has 18 years of teaching experience. She is an English major and was fully trained to teach English for primary school students. Her school is located right in the middle of 
Vol. 7, No. 4, 2018, E-ISSN: 2226-6348 @ 2018 HRMARS

the town area in Melaka Tengah District and the majority of the students there speak English at home.

This small scale case study has its own limitations. The data is gained by using only one method, i.e., via semi-structured interview. The participants are all female and they are all teaching in Melaka Tengah District. They are trained to teach English and they have more than 7 years of teaching experience. As such, the findings of this study will not represent the teachers with different gender, or teaching in different districts or states, or those with no teaching experience or training to teach English. It is also important to note that the main aim of the qualitative study is not to generalize the findings to all or to most Malaysian teachers in Malaysia or in Melaka who are teaching primary school English language subject; however it is to get in-depth perceptions and information on the teachers' practices when it comes to using storytelling technique in teaching English.

\section{Findings and Discussion}

\section{How are the storytelling strategies perceived by the teachers?}

The first research question is to know how the storytelling strategies are perceived by the English teachers. To know their perceptions towards storytelling, the three teachers were asked to define 'storytelling' by using their own words during the interview. These are their definitions of storytelling:

Storytelling is not just about the text, it is not just about the story, it can be your experience as well - you can tell your daily experience. From my understanding, we can get a real life story or maybe some story that they already know and retell them in class and make it in a more fun way with some additional props to make it more alive, make it more interesting for them to listen and to understand the lesson that we are going to teach them. (Teacher 1)

I think storytelling does not necessarily mean you have to take a story book from the library and read out to your pupils. It can be any story. It can be what you have in your textbook. It can be pupils sharing their experience. In my opinion, this is storytelling. (Teacher 2)

Storytelling is a way for pupils to communicate and then express their thoughts and ideas. They will be able to share their experience. We do not have to do it too formally, we can also do it informally where the pupils can express their own ideas or any story they like. (Teacher 3)

From the three definitions given, it can be concluded that the three teachers do have some similarities in their definitions of storytelling. They perceive storytelling not just as an activity where the teacher reads a story from a book, but also refers to an event where the teacher or students share their experiences, thoughts, ideas or real life events verbally during the lessons. They also agree that the setting for this storytelling session should be done informally, in a more relaxing manner where all the students will have the chance to participate. They usually would 
Vol. 7, No. 4, 2018, E-ISSN: 2226-6348 @ 2018 HRMARS

pay less attention to any grammar mistakes made during the storytelling session but prefer to focus more on building listening and speaking fluency; which would help to improve the students' communication skills.

Their definitions of storytelling are not much different from the literature. Maynard (2005; cited in Sulaiman Keshta, 2013) defined stories as the way people communicate their experience, understand the experience of others, liberate their imaginations, and make sense of the world and their own position within it. Stories are how people make sense of themselves and their worlds. Storytelling is uniquely a human experience that enables us to convey, through the language of words, aspects of ourselves and others, and the worlds, real or imagined, that we inhabit (Sulaiman Keshta, 2013). The formal telling of stories has a history full of treasure and delight. Even informally, in daily conversations, the use of storytelling to communicate ideas and to express one's experiences is evident. Eric Hoffer, an American philosopher, claims that humans have an innate need to tell stories, and according to him, we must 'story' our lives to make order and sense out of them (cited in Fitzgibbon \& Wilhelm, 1998).

The teachers' perceptions towards storytelling is highly supported by Roney (1996) as well as he stated that storytelling is one of the most powerful forms of art/communication known to humans and this explains why it possesses such great potential as a teaching-learning tool. In this case, it helps the students to express themselves freely without having to consciously worry about making grammar mistakes. The teachers indirectly concur with Roney (1996) when they mentioned that storytelling does bring a lot of benefits as a teaching-learning tool in their English lessons. These are some of the main benefits mentioned by the teachers during the interview:

The things that I see that have a big impact on my student is they have more ideas to write because sometimes whatever I shared is something they haven't experienced before - so when I tell them the story from my own experience, they will get new ideas - something new that they can write - that's how it helps them. (Teacher 1)

First and foremost, I think storytelling is fun. Ok - it's not just chalk and talk, teachers talking most of the time, but pupils are also involved in the storytelling session - they ask questions (among them), they answer, we ask (questions), they answer and so on - so pupils are involved, so that is important. (Teacher 2)

They are able to speak confidently - they are able to express their thoughts and then their experience and the most important thing is that they are able to widen their vocabulary - improve their grammar, their vocab - their speaking and also listening. So meaning that, if they learn new words, they learn in context. And then grammar, they know how to use it in context too. (Teacher 3 )

The teachers also stated other benefits of using storytelling in their English classrooms during the interview. The benefits that they have mentioned could be summarised as follows: 1) storytelling helps to improve the students' listening and speaking skills; 2) they could focus more on sharing the stories, experience or opinion rather than grammar; 3) storytelling is fun for the students because it is not just chalk and talk; 4) it gives big impact on students' writing, especially when 


\section{INTERNATIONAL JOURNAL OF ACADEMIC RESEARCH IN PROGRESSIVE EDUCATION AND}

DEVELOPMENT

Vol. 7, No. 4, 2018, E-ISSN: 2226-6348 @ 2018 HRMARS

generating ideas; 5) the students are able to speak more confidently to express their thoughts, opinion and experience; 6) storytelling helps to reduce teacher talk time since the students are actively involved; 7) storytelling helps to create relaxing and informal atmosphere; 8 ) it helps to widen the students' vocabulary and they are able to learn new words in context; 9) storytelling can be a starting point for many other activities afterwards; 10 ) it provides more opportunity for three-way interactions during storytelling, i.e., teacher-students, students-teacher and studentsstudents; and lastly, 11) the students are able to learn grammar in context.

To dig deeper into their beliefs, the teachers were asked to give their opinion and honest thoughts about using storytelling in the classroom. Teacher 1 said that she loves storytelling in class because it is her favourite part of the lesson. She could relate to her own experience, which is more interesting compared to what the students read in books. During the interview, she stated, "Mostly I use my own experience - that is more interesting to them - as compared to what they read in books. That is the fun part - a real life story." When she shares some stories, she thinks that the students would feel more encouraged to share theirs. She mentioned:

Actually it (storytelling) is my favourite part - because I am a storyteller - I love to do storytelling in class...sometimes I try to relate it with my own experience, with their (pupils) own experience. I also like them to share whatever they have or whatever they experienced before...that is how I encouraged them to speak in class.

As for Teacher 2, she thinks that storytelling can help to motivate and encourage students from good classes to speak freely by providing some cues. As for average and weaker classes, storytelling is a good activity for them to practice their communication skills. She provided them with sufficient vocabulary so that they could give their opinion or share their story or experience. To her, if she could encourage the weak and average students to utter two or three sentences during the storytelling sessions, that would be considered as a great achievement. As she stated, "If they could explain what did they do during the holidays - even though it's like in a few sentences, to me it is like a storytelling. They are narrating something that they have done."

To Teacher 3, storytelling is not new as she stated, "Storytelling is not something new because storytelling is the thing we do - we always do in the classrooms." She feels comfortable to use storytelling in class and finds it quite convenient as there is one topic in the textbook called 'World of Stories' that she frequently uses as a platform for storytelling sessions.

It is important for the researchers to emphasize that the new Malaysian primary school syllabus, i.e., KSSR was introduced as an effort to restructure and improve the current curriculum to ensure that the students will have the relevant knowledge, skills and values to face the challenges of the 21st century. Because the element of language arts is included in the new KSSR English curriculum and syllabus, this study is interested to know the teachers' perceptions towards the idea of inserting storytelling as a part of the English lessons. In this vein, when the teachers were asked whether storytelling is relevant to KSSR, Teacher 1 thinks it is very relevant because KSSR's focus is on fun learning. In her opinion, storytelling can definitely create fun lessons and learning experience. She stated: 
Yes, to me is very relevant because in KSSR, the focus is fun learning - and one way to make the learning fun is by giving them a story that they can relate with the topic - and then they have the chance to speak when they tell their own story - you know children, when we tell them something, when we give them a topic or story - they have their own story to share.

For Teacher 2, she thinks storytelling is very relevant to KSSR if the teachers have the time to do storytelling, especially during Language Arts. For Teacher 3 , she thinks storytelling is relevant to KSSR as well because students can express themselves and relate to what they have read with their own experience.

Within KSSR, there is the elements of higher order thinking skills or also known as HOTS that needs to be included as a part of the lessons and also assessments. This is to ensure that students would have relevant knowledge, skills and values to face the challenges of the 21st century. Concerning HOTS, this study is interested to know the teachers' perceptions towards the relevance of storytelling in regards with HOTS. Teacher 1 thinks that storytelling is good for HOTS because she could ask HOTS questions after each storytelling session to make the students think further. This helps in fostering thinking skills and thinking for themselves. Like she said:

I always ask questions after I tell them the stories, I like them to think - I will ask questions that make them think further. I think that helps to encourage them with thinking skills let them think for themselves.

For Teacher 2, she thinks the teachers can ask HOTS questions based on the stories heard or read. So, to her, HOTS is "not just what they remember, they can explain why and also their preference." By using storytelling, it helps her students to remember the details of the story and also enhance their ability to explain the reasons why or their preference about certain details or parts of the story.

Teacher 3 thinks it is difficult for her students to answer HOTS questions, thus it becomes a challenge for her to teach them higher order thinking skills. She stated:

I find that it's difficult for them (pupils) to answer HOTS question because I think due to, you know, our kids now do less reading - they are more into gadgets. They don't like reading. That's why they cannot - especially for English's HOTS questions, they cannot relate the questions with the story.

However, she emphasises that storytelling does provide ample opportunities to ask HOTS questions to her students.

To help capture their perceptions towards their own creativity level and self-confidence in using storytelling, the teachers were asked to self-rate themselves in three areas: 1) creativity level to create fun, pleasurable and memorable English lessons; 2 ) level of confidence to use storytelling in the classrooms; and 3) creativity level to create lessons based on storytelling strategies. They 


\section{INTERNATIONAL JOURNAL OF ACADEMIC RESEARCH IN PROGRESSIVE EDUCATION AND}

DEVELOPMENT

Vol. 7, No. 4, 2018, E-ISSN: 2226-6348 ๑ 2018 HRMARS

were asked to rate themselves from the scale of 1 to 10 , where 1 is the lowest score and 10 is the highest. Based on the self-rating scores, the study found that the teachers are very confident in two areas; first, they are confident to use storytelling strategies with high achievers and good students because the lessons can be conducted almost 90\% in English. Second, their students tend to enjoy the lessons that involve storytelling strategies more because they have fun during the lessons and they could learn what the teacher wants them to learn.

However, they feel less confident and face challenges and their own self-doubt in three areas: 1) they face difficulties in getting very interesting story that relates to certain difficult topics or issues in the syllabus; 2) they are worried when they have to use a lot of mother tongue and translation when telling the stories to low achievers and average students; and lastly, 3) they have doubts whenever they use storytelling strategies in the classroom since they are unsure whether they are using the right one.

Based on their responses, it is obvious that their perceptions towards their own creativity level and self-confidence in using storytelling strategies is weighing heavily on their own knowledge and skills in storytelling and also the students' proficiency level. They admitted that they enjoyed using storytelling activities for high achievers and good students, but they were unsure about using the same strategies with low achievers and average students. Perhaps this is heavily related to their own self-doubt about their own knowledge in storytelling strategies since they never received proper training in using storytelling and how to use it to cater for students with different abilities.

\section{How are storytelling strategies used to teach English in the classrooms?}

The second part of the first research question asks on how storytelling strategies are used to teach English in the classrooms. When asked, the teachers stated that they have used storytelling strategies in their English classes in different ways: 1) to create fun, pleasurable and memorable activities; 2) to encourage active participations among the students; 3) to provide nonthreatening outlet for students to express themselves, so that it helps to build confidence and motivation to use English; 4) to narrate, retell, share, exchange new stories or well-known stories; $5)$ to introduce new stories from local or different countries, or to introduce students to new experience or adventures through narrative; 6) to deliver the skills - listening, speaking, reading, writing and also grammar and vocabulary through telling stories, sharing experiences, exchanging opinions and expressing ideas; 7) to provide the opportunity for students to practice their nonverbal communicative tools like gestures, facial expressions, body movements, eye contact etc.; and lastly, 8) to use as a stepping stones for other/further activities to teach different skills.

Teacher 1 added that she prefers to use storytelling strategies by relating the topic that she is teaching with her own experience. This indirectly will encourage the students to share their own stories or experience. She stated, "They (the pupils) have their own story to tell...We can learn something from them. Like we never expected their way of thinking - they think differently, their view of life is different." To her, this is the most exciting part about using storytelling in her English class. She could always learn new things from her students and learn about how her students think. 
INTERNATIONAL JOURNAL OF ACADEMIC RESEARCH IN PROGRESSIVE EDUCATION AND DEVELOPMENT

Vol. 7, No. 4, 2018, E-ISSN: 2226-6348 @ 2018 HRMARS

Teacher 2 uses storytelling strategies to teach the skills in English due to its element of fun. It is being utilised mostly due to its added bonus, which is fun equals to longer information retention. She said:

I've tried to use storytelling to teach the skills and I think it's workable because the most important thing is my pupils enjoy it. They remember the story, they remember the vocabs, they remember the moral values. Because they enjoy it, they remember better.

Her reason for using storytelling is supported by Cooper (1989; cited in Hsu, 2015) when he stated that storytelling is an ideal method of influencing a child to associate listening with pleasure, and increasing a child's attention span and retention capacity, and also broadening vocabulary and introducing the symbolic use of language.

As for Teacher 3, she thinks storytelling strategies are the best in providing the opportunity for her to teach non-verbal communication skills, such as facial expression and gestures. To her, these are the added bonus of using storytelling strategies. She mentioned:

When you do speaking activities, they can express themselves through facial expressions - because from the facial expression, then we know what the person is trying to tell you. So the message can be sent through the facial expressions. You can do this through storytelling.

Based on the interviews, the teachers mentioned various ways on how they have applied storytelling strategies in their English classrooms with their students. However, their storytelling strategies usage is still considered very minimal and underutilised. This is based on their own confessions that they are lacking in knowledge to fully incorporate storytelling strategies with the topics and the skills that they are teaching. There are certain topics or skills that they are unsure of to integrate storytelling strategies, for instance, when they are teaching grammar. Teacher 1 and Teacher 2 mentioned:

I still haven't got the idea on how I can use storytelling for grammar - but for listening, speaking and reading, I think it is very relevant and is very suitable to use. (Teacher 1 )

I think all the teachers should try storytelling because it's very flexible. We can do anything we want, we can focus on any skill that we want. We can teach them anything. We can also teach them grammar, although I've not tried that before. (Teacher 2)

The above excerpts clearly show that the teachers are unsure of how to insert storytelling in grammar lessons. As for Teacher 3, she stated, "I'm not sure I'm doing the correct (storytelling) strategies - I'm doing it but I'm not so sure whether it is (actually) a storytelling strategy." This lack of knowledge and self-doubt has a great impact on her confidence in using storytelling strategies in the English classrooms. It is seeded from lack of proper training on the usage of storytelling strategies. If only these teachers were given adequate storytelling training, it would help them to be more confident in creating wonderful and useful storytelling activities that could be integrated in listening, speaking, reading, writing, grammar and vocabulary lessons. Adequate 
INTERNATIONAL JOURNAL OF ACADEMIC RESEARCH IN PROGRESSIVE EDUCATION AND DEVELOPMENT

Vol. 7, No. 4, 2018, E-ISSN: 2226-6348 ๑ 2018 HRMARS

storytelling training would also allow them to explore many other ways of using storytelling in their English classrooms, apart from the ones that they have mentioned during the interviews.

There are variety of ways for storytelling to be utilised in the English classrooms supported by numerous literature. For instance, according to Green (20004; cited in Hsu, 2015), stories can be used in today's classroom with a diversity of functions, including sparking student interest, aiding the flow of lectures, making material memorable, overcoming student resistance or anxiety, and building rapport between the teachers and the learners, and among students themselves. Storytelling strategies also help to change the class environment from a dry, boring one to a warm environment full of student concentration, participation and production (Kalantari \& Hashemian, 2015). An EFL/ESL lesson that starts with a story could help to put the students at ease and allow them to understand something concrete before going on to the related abstract concept (Martinez, 2007; cited in Kalantari \& Hashemian, 2015). Storytelling can also encourage cooperative activity, encompass holistic perspectives, value emotional realities, link theory to practice, stimulate students' critical thinking skills, capture complexities of situations, reveal multiple perspectives, make sense of experience, encourage self-review and construct new knowledge (Alterio, 2004).

How often do the teachers use the storytelling strategies in their lessons and for what purpose? The second research question for this study focuses on the frequency, i.e., how often the teachers use the storytelling strategies in their lessons and for what purpose. When asked about how often they use storytelling strategies in their English classes, they said that they only use storytelling for certain topic and skills in the syllabus, for example for 'World of Stories' section in the English curriculum and syllabus. They usually use storytelling as a part of the lesson; for either pre-, while-, or post-activity. According to them, they could not use storytelling all the time because it might not be suitable with all of the topics or the skills stated in the syllabus. Hence, they only use it whenever it suits the lessons. Teacher 2 stated, "I try to make use of this (storytelling) based on - I cannot run away from the syllabus - so based on the topics, on the skills... try to incorporate this (storytelling)." Teacher 2 also stated that due to time constrain to complete the syllabus, she could not use storytelling as often as she wanted. She said:

I think it (storytelling) is very relevant - especially if we have the time. Due to insufficient time, maybe (that's why) most teachers put that aside. I cannot carry out storytelling often, frequently. Maybe once a week or alternate weeks.

In this case, the pressure of completing all the topics in the textbooks is not just a major concern for Teacher 2. In fact, all three teachers are under a lot of pressure to complete their syllabus on time because they have to make sure that their students are well-prepared for the school based assessments/examinations and also for the public examinations. Thus, they feel that storytelling is an activity that equals to 'a guilty pleasure' that they could not afford to do all the time. That is the main reason why the teachers do not use storytelling strategies often enough in their English classrooms. 


\section{INTERNATIONAL JOURNAL OF ACADEMIC RESEARCH IN PROGRESSIVE EDUCATION AND}

DEVELOPMENT

Vol. 7, No. 4, 2018, E-ISSN: 2226-6348 @ 2018 HRMARS

The other reason why storytelling strategies are not frequently used is because of the beliefs that creating and planning storytelling activities require a lot of time and effort. Again, this misconception is seeded from the teachers' lack of knowledge and proper training in storytelling. Storytelling does not always require a lot time and effort to plan. For instance, it could be a simple activity like asking the students how their day went. This is enough invitation for the students to share the highlights of their day. The simple invitation for them to share or tell a story indirectly create a very simple storytelling activity without taking so much time of preparation on the teacher's part (Gere, Kozlovich, \& Kelin, 2002).

As for the purpose of them using storytelling as a strategy during their English lessons, they said that storytelling is mainly used as a part of the lesson, i.e., for either pre-, while- or post-activities. To them, storytelling is very useful as a stimulation activity to generate interests or ideas, a stepping stone: that is a strategy that could catapult the lessons into many or other different directions such as generating ideas for writing or speaking skills; one of the activities that enable students to practise their non-verbal communication skills; enable the teacher to dig deeper into what the students already know or what they understand; and finally, storytelling helps in teaching other skills indirectly, in a fun way. During the interview, Teacher 1 stated:

I use storytelling as a starting point to teach my lesson. I will start to tell them my own story that have some relation to the topic and the lesson. For example, I like to use storytelling first before they write so that they can generate ideas.

This simple strategy helps to give a great impact on her students' writing because the stories that she tells help the students to generate and develop ideas. Teacher 1 also uses storytelling to develop her students' higher order thinking skills. She revealed:

I always ask question after I tell them the stories. I like them to think. I will ask questions that make them think further. I think that helps in encouraging them to think...encourage them to think for themselves.

For Teacher 2, she mentioned, "We can come out with many activities based on storytelling. We can start with storytelling and it can go to many, many directions." For the purpose of using storytelling in her lesson, Teacher 2 said, "Mostly I use storytelling during my pre-activities. It could be pre-listening or pre-speaking. So I have my (storytelling) activities during that time."

Teacher 3 finds storytelling helps her a lot in enabling her students to practice their non-verbal communication skills. She stated:

When you do speaking activities, they can express that (facial expression, gestures etc.) You can do this through storytelling. From the facial expression, then we will know what the person is trying to tell - so the message can be sent through the facial expression.

She also mentioned that storytelling helps in teaching her students many language skills. She said: 

DEVELOPMENT

Vol. 7, No. 4, 2018, E-ISSN: 2226-6348 @ 2018 HRMARS

Storytelling enables the pupils to speak confidently, they are able to express their thoughts, give their opinion and they can learn a lot - they learn how to speak, how to write, and widen their vocabulary and also improve their grammar.

The responses show that some initiatives have been taken to insert some storytelling strategies in their English lessons. However, their purposes of using storytelling strategies in the classrooms are still marginal. This might be the result of insufficient training to use storytelling in the classrooms. There are many studies done to illustrate various purposes of storytelling in the English classrooms. For instance, Lwin's (2009) study shows that storytelling is a very apt platform to teach messages of moral concerns; not just from our own culture but also morals from different cultures. The stories, especially the folktales, taken from our own local culture is helpful to instil some desired moral lessons in regards with our own culture and customs. By using stories from other countries, the teachers are able to share the universal moral concerns from many lands. Lwin (2009) stated that the folktales from other countries usually share the same universal moral concerns such as honesty, kindness and generosity, as opposed to jealousy, greed and pride. These issues are prevalent in any culture, which shows that the relationship of narrative form, function and field in tales with the moral seems to appear in many folktales from different countries.

Another interesting purpose of storytelling is to be used as a tool to develop the imagination, which in turn builds on problem-solving competencies (Mallan, 1992; cited in Nor Hasni, Michi Farida, \& Sharifah Zurina, 2011). Developing imagination is something that Malaysian teachers usually tend to ignore with the excuses of 'not enough time,' 'not included in the syllabus,' and 'not tested in the exam.' If storytelling is being used effectively in the classrooms, both telling a story and listening to a well-told tale encourages students to use their imaginations. Developing the imagination can empower students to consider new and inventive ideas. Consequently, developing the imagination can contribute to self-confidence and personal motivation as students envision themselves to be competent and able to accomplish their hopes and dreams (Nor Hasni et al., 2011).

\section{What challenges do teachers experience while working with storytelling strategies in their lessons and how do they deal with these challenges?}

The third research questions focuses on the challenges that the teachers have experienced while working with the storytelling strategies in their English lessons and how do they deal with these challenges. The challenges that they have mentioned are related to four areas: 1) insufficient training; 2) insufficient teaching materials and big class size; 3) students' lack of readiness; and 4) a very rigid education system.

The first challenge is insufficient training. This insufficient training refers to no proper training or guideline given to use storytelling in English lessons. Thus, the teachers feel that they have insufficient knowledge about storytelling, which lessen their confidence to use storytelling in the classroom. Teacher 2 stated, "One of my biggest obstacles to use storytelling in the classroom is insufficient knowledge because now, I do storytelling based on my own personal experience." Thus, they face their own self-doubt in choosing the best storytelling strategies for certain skills 

DEVELOPMENT

Vol. 7, No. 4, 2018, E-ISSN: 2226-6348 @ 2018 HRMARS

or activities. Teacher 3 mentioned, "I want to use more storytelling (but) I'm not sure whether I'm using the correct storytelling strategies in the classroom." Teacher 2 added, "I'm using the (storytelling) strategies, but I don't know whether they are (truly) storytelling strategies." They are also unsure of how to integrate certain skills with storytelling strategies, for example in grammar lessons. As Teacher 1 said, "Storytelling helps in teaching listening, speaking, reading, writing and vocabulary but for grammar part, I still haven't got the idea how I can use storytelling for grammar."

The second challenge that they face is insufficient teaching materials and big class size. They sometimes faced problems to find appropriate teaching materials to use for storytelling because the school has insufficient teaching materials. Teacher 1 mentioned, "Sometimes I could not find the suitable materials (for certain topics) so I just tell a story without any help from any teaching aids or props." Another obstacle to carry out storytelling strategies is due to overcrowded classes. Big classes is an issue for the teachers because it is difficult to conduct effective storytelling activities with 40 to 45 students in a class. Sometimes it is too much a burden for them to monitor each student's progress during the activities. Teacher 1 stated, "Sometimes my voice could not reach the students who sit at the back of the class. That's why I always find a way to get them together (re-grouping or re-arrange them) - maybe just ask them to sit down on the floor."

The third challenge that they face is the students' readiness to using storytelling in lessons (or in their cases, the lack thereof). The students who usually give them very little cooperation during storytelling activities are the low proficiency students. The teachers could not use $100 \%$ English with them and they have to resort to use the mother tongue. Teacher 3 stated:

I know that we are not allowed to use our mother tongue during English lessons. But in order to make them understand, especially for the weak classes, I have to use some of their mother tongue, but not $100 \%$. If I use $100 \%$ English with them, some of the students will say to me, "Cikgu, saya tak faham" (Teacher, I don't understand).

Teacher 2 also faced the same dilemma. She mentioned:

If it is a good class, the high achievers, I would use $90 \%$ of English with them. If they are the weaker ones, I have to use their mother tongue for reinforcement, to ensure that they understood the stories. Normally, I will start with English first. If I find that they do not really understand, then I will use some of their native language.

These students are not interested in learning English as well, so sometimes it is very hard for the teacher to gain their interests in storytelling. Teacher 1 commented:

We don't expect everyone to like the stories or everybody to fully understand the stories. Some of them are not interested at all, especially the weaker classes. Even though I'm telling the stories by using the props and the teaching aids and with passion (by using different tones, expressions, gestures etc.), they still don't want to listen. They are not interested. It is very hard to make them to be attracted to the stories. 
The last challenge that they face is due to the rigid education system. The teachers are 'forced' to follow strictly to the syllabus due to the exam-oriented education system. Teachers also faced time constrain to prepare good lessons due to so many extra co-curricular activities and other out of class responsibilities. Teacher 3 mentioned, "We don't have much time, ample time, for us to get to teach English in a fun way. To set up such lessons will take time - time to prepare all the materials to teach them, to hook their interests." The teachers also mentioned that the primary school students are being burdened by so many subjects. At the moment, they are learning about 10 to 12 subjects under the new KSSR syllabus. Teacher 3 pointed out, "We have so many subjects; Maths, Science and then now the new subjects like TMK, RBT, History..."

To deal with these challenges, the teachers have taken a few manageable steps. In dealing with insufficient training for using storytelling strategies, they have taken their own initiatives to learn from their friends and colleagues. One teacher, Teacher 3, managed to collaborate with local teachers and some English teachers from Singapore, under her school two-way collaboration initiatives. They also learned from their former English teachers; by using the same effective techniques and strategies that their teachers have used when teaching them during their schooling years. Mostly they learned from their own experience, by trial and error and adopt and adapt. They are in dire needs of training and thus, they have expressed their willingness to attend any future short courses or in-service training organised by the Ministry of Education to upgrade their knowledge and teaching skills.

In dealing with insufficient teaching materials, the teachers have taken their own initiatives to develop their own teaching materials. They have tried within their own abilities and capabilities to find relevant resources that relates to the topics, select better materials that are more suitable for the students' level with simpler text and words and create a module that cater for all the skills and students' level. To help low proficiency students, the teachers provide them with ample vocabulary so that they could participate during the storytelling activities.

The last research question managed to unearth several challenges that the teachers faced in regards with storytelling and also managed to discover how resilient they are to overcome those challenges. Although they successfully tried to overcome most of the challenges, a few challenges still remain unmet. For instance, insufficient training. For teachers to learn from friends and colleagues or even engage in collaborations do not entirely solved the real issue of insufficient training. The teachers require proper training and adequate courses that relate to storytelling and how to incorporate storytelling strategies within the textbook topics, the skills and the syllabus. The interviews revealed that the teachers know how beneficial storytelling strategies are in their English classrooms and fully aware that storytelling helps to make their lessons more fun, memorable, and meaningful. However, insufficient training and lack of knowledge have impacted on their self-esteem and confidence to use storytelling in their lessons.

In a study done by Sim and Kim (2013), they discovered that there is a relation between confidence and proper training. The teachers in their study indicated that they have gained motivation and confidence after attending a storytelling workshop. This increased confidence 


\section{INTERNATIONAL JOURNAL OF ACADEMIC RESEARCH IN PROGRESSIVE EDUCATION AND}

DEVELOPMENT

Vol. 7, No. 4, 2018, E-ISSN: 2226-6348 @ 2018 HRMARS

played a crucial role in the teachers' ongoing attempts to acquire new storytelling skills in their teaching practice and naturally helped them to reconstruct and adapt the knowledge that they have obtained during the workshop to their students' level. It is possible to speculate that the teachers have gained personal confidence to teach storytelling skills during the course. The teachers' increased confidence obtained during the workshop has enabled them to start using new teaching approaches and strategies, which are different from their previous routines.

\section{Conclusion}

In answering the first research question, i.e., on how the storytelling strategies are perceived and used by Malaysian primary school teachers in the English classrooms, the researchers found that these teachers do have positive perceptions towards storytelling strategy. They believe that storytelling does bring a lot of benefits to their English lessons. One of the teachers, i.e., Teacher 1 , really loves storytelling based on her own personal experience being exposed to storytelling and storytelling competitions by her own primary school teachers. As Jonhson (1994; cited in Phipps \& Borg, 2009) mentioned, language teachers' beliefs about teaching and learning have a powerful effect on teachers' pedagogical decisions. In this case, Teacher 1's strong belief is highly influenced by her own experiences as a learner. She loves storytelling because she, herself, was exposed to storytelling by her English teachers and she had the experience in training and participating in storytelling competitions. Her love for storytelling is powerfully influenced by her own positive experiences as a learner and this positive influence is well established by the time she went to the university and teacher training college. As for Teacher 2 and Teacher 3, their beliefs in storytelling stemmed from their classrooms experiences and practices. As Borg (2003) stated, classroom experience influences cognitions unconsciously and/or through conscious reflections. This is true when the two teachers stated during the interview that they love storytelling because they have tried the strategies in their lessons and they could see the students really enjoyed storytelling activities and have gained a lot of benefits from them.

Therefore, it can be reported from this case study that there is a connection between the relationships of teachers' mental constructs to what they do in the language teaching classroom. As Borg (2012; cited in Birello, 2012) stated, if we want to promote change in the classrooms, understanding what the teachers do is not enough, we also need to understand and look at their beliefs. In this case, if most English teachers have the same belief as Teacher 1, Teacher 2 and Teacher 3, it is possible for big changes to take place in Malaysian classrooms. The idea of using storytelling as a tool in teaching English would thrive and the students would gain a lot of benefits from it.

As for the question of how the teachers use storytelling strategies in their English classrooms, the findings show that they use storytelling to create fun, pleasurable and memorable activities; to encourage active participations among the students; to help in providing non-threatening outlet for students to express themselves, so that it helps to build confidence and motivation to use English; to help in narrating, retelling, sharing, exchanging new stories or well-known stories; to introduce new stories from local or different countries, or introduce students to new experience or adventures through narrative; to deliver the skills - listening, speaking, reading, writing and also grammar and vocabulary through telling stories, sharing experience, exchanging opinion and 

DEVELOPMENT

Vol. 7, No. 4, 2018, E-ISSN: 2226-6348 ๑ 2018 HRMARS

expressing ideas; to provide the opportunity for students to practice their non-verbal communicative tools, like gestures, facial expressions, body movements, eye contact etc.; and lastly, as a stepping stones for other/further activities to teach different skills. The teachers believe that storytelling strategies offer a lot of advantages to their students.

As for the second research question, in terms of how often the storytelling strategies are used in the English classroom, the findings show that the teachers neither use storytelling often nor utilise it to its fullest potential. This is probably due to their insufficient knowledge about how to incorporate storytelling in their daily class routine. The teachers admit that they are unsure whether the storytelling strategies that they have used in their lessons are appropriate. They only use storytelling strategies for certain topics or skills; when they think they are appropriate or relevant. Perhaps that is also the reason why they only use it minimally, as parts of the lessons or only for lessons that relates to reading skills, reading stories or texts. If they have adequate training in utilising the storytelling strategies, the teachers would perhaps know that they could actually incorporate storytelling with any daily class routine without having to read a text or a story.

The findings for the last research question show that the teachers face many challenges to carry out storytelling in the classroom. Fortunately, the teachers could overcome some of these challenges by finding solutions within their own abilities and capabilities. One challenge that they could not overcome though is in upgrading their knowledge and skills in regards with storytelling strategies. They are willing to attend in-service training or short courses if this option is offered by the Ministry of Education Malaysia. Unfortunately, there is no such training given to in-service teachers. Perhaps the Ministry of Education Malaysia could provide short courses for the English teachers in the future so that they could upgrade their knowledge and skills, which indirectly will benefit the students in the long run.

This study has highlighted numerous benefits of using storytelling in teaching and learning of English. It would be a tremendous loss for teachers and students if storytelling strategies are not being fully utilized in Malaysian classrooms. The Ministry of Education Malaysia should take advantage of the fact that the school setting or the school background do not affect teachers' positive outlook on the use of storytelling in the classrooms. With sufficient training and guidance from the ministry, it would be possible for all Malaysian English teachers to use storytelling as a teaching tool in their lessons, regardless of their school locations or school backgrounds. Perhaps the training could start with the pre-service teachers, at the teacher training colleges or universities. It would be fruitful to equip the future teachers with storytelling skills and strategies so that they could implement storytelling from their very first day of being a teacher. As for curriculum developers, they could help to put more emphasis on storytelling by including more storytelling activities in the KSSR syllabus other than for language arts and 'World of Stories.' Storytelling is one of the teaching strategies that emphasizes on fun learning and creating an informal atmosphere in the class, which proves to be conducive to language learning. Anyone who is anyone in education should take note on the importance of storytelling and they should play their roles in ensuring storytelling to be fully utilized in teaching and learning of English language. 
INTERNATIONAL JOURNAL OF ACADEMIC RESEARCH IN PROGRESSIVE EDUCATION AND DEVELOPMENT

Vol. 7, No. 4, 2018, E-ISSN: 2226-6348 @ 2018 HRMARS

\section{Corresponding Author}

Abu Bakar Razali (PhD), Department of Language and Humanities Studies, Faculty of Educational Studies, University Putra Malaysia, 43400 UPM Serdang, Selangor Darul Ehsan, Malaysia.

Email: abmr_bakar@upm.edu.my

\section{References}

Alterio, M. (2004). Using storytelling to enhance student learning. The Higher Education Academy, 1-5.

Anis, M., Mahani, M., Latisha Asmaak, S., \& Surina, N. (2009). A Study of Collaborative Learning among Malaysian Undergraduates. Asian Social Science, 5(7), 70-76.

Birello, M. (2012). Teacher Cognition and Language Teacher Education : beliefs and practice. A conversation with Simon Borg. Bellaterra Journal of Teaching \& Learning Language \& Literature, 5(2), 88-94.

Borg, S. (2003). Teacher cognition in language teaching: A review of research on what language teachers think, know, believe, and do. Language Teaching, 36(2), S0261444803001903.

Choy, S. C., \& Troudi, S. (2006). An Investigation into the Changes in Perceptions of and Attitudes Towards Learning English in a Malaysian College. International Journal of Teaching and Learning in Higher Education, 18(2), 120-130. Retrieved from http://www.isetl.org/ijtlhe/

DiCarlo, S. E. (2009). Too much content, not enough thinking, and too little FUN! AJP: Advances in Physiology Education, 33(4), 257-264.

Fitzgibbon, H. B., \& Wilhelm, K. H. (1998). Storytelling in ESL/EFL classrooms. TESL Reporter, 2131.

Gere, J.,Kozlovich, B-A \& Kelin, D. A. (2002). By Word of Mouth: A Storytelling Guide for the Classroom. Pacific Resources for Education and Learning (PREL).

Hsu, T.-C. J. (2015). Telling tales: Using storytelling to teach EFL kindergarten students in Taiwan. International Journal of Research Studies in Education, 4(4), 13-25.

Kalantari, F., \& Hashemian, M. (2015). A Story-Telling Approach to Teaching English to Young EFL Iranian Learners. English Language Teaching, 9(1), 221.

Lim, T. D. (2013). Analyzing Malaysian English classrooms: Reading, writing, speaking \& listening teaching strategies, 1551063, 60. Retrieved from http://proxyau.wrlc.org/login?url=http://search.proquest.com/docview/1497029246?acco untid=8285\%5Cnhttp://vg5ly4ql7e.search.serialssolutions.com/?ctx_ver=Z39.882004\&ctx_enc=info:ofi/enc:UTF8\&rfr_id=info:sid/ProQuest+Dissertations+\&+Theses+Full+Text\&rft_v

Lwin, S. M. (2009). Revisiting a Structural Analysis of Folktales: A Means to an End? The Buckingham Journal of Language and Linguistics, 2(1)(September), 69-80.

Merriam, S. B., \& Tisdell, E. J. (2016). Qualitative research: A guide to design and implementation. The Jossey-Bass higher and adult education series.

Nor Hasni, M., Michi Farida, A. H., \& Sharifah Zurina, S. K. (2011). The effectiveness of storytelling in enhancing communicative skills. Procedia - Social and Behavioral Sciences, 18, 163-169.

Normazidah, C. M., Lie, K. Y., \& Hazita, A. (2012). Exploring English Language Learning And Teaching In Malaysia. GEMA Online Journal of Language Studies, 12(1), 35-51.

Phipps, S., \& Borg, S. (2009). Exploring tensions between teachers' grammar teaching beliefs and 
INTERNATIONAL JOURNAL OF ACADEMIC RESEARCH IN PROGRESSIVE EDUCATION AND DEVELOPMENT

Vol. 7, No. 4, 2018, E-ISSN: 2226-6348 @ 2018 HRMARS practices. System, 37(3), 380-390.

Roney, R. C. (1996). Storytelling in the Classroom: Some Theoretical Thoughts. Storytelling World, 9, 7-9.

Roselina, S. (2009). Soft skills at the Malaysian institutes of higher learning. Asia Pacific Education Review, 10(3), 309-315.

Shirley, J. M. (2005). Storyteller, Story-Teacher: A Portrait of Three Teachers' Use of Story in Elementary Classes. Technology.

Sim, J.-Y., \& Kim, E.-H. (2013). A Case Study of a Storytelling Workshop: The Impact on Teachers' Classroom Practice and Perception Change. English Language \& Literature Teaching, 19(3).

Sulaiman Keshta, A. (2013). Using storytelling in teaching English in Palestinian schools: perceptions and difficulties. Education Journal, 2(2), 16-26.

Suzuki, K. (2000). Teacher's English Storytelling: Stories and Skills to Tell. 鈴木克彦, 45, 191-200. Retrieved from

http://ir.nul.nagoyau.ac.jp/jspui/bitstream/2237/5118/1/KJ00002354448.pdf

Thang, S. M., Ting, S. L., \& Nurjanah, M. J. (2011). Attitudes and Motivation of Malaysian Secondary Students towards learning English as a Second Language: A Case Study. The Southeast Asian Journal of English Language Studies, 17(1), 40-54. Retrieved from http://journalarticle.ukm.my/2047/

The Star Online. (2017). English proficiency still a big problem for many Malaysian grads. The Star Online. Retrieved from https://www.thestar.com.my/news/nation/2017/01/21/englishproficiency-still-a-big-problem-for-many-msian-grads/

Yin, R. K. (2009). Case Study Research: Design and Methods. Essential guide to qualitative methods in organizational research (Vol. 5). 